\title{
MANAGING DIMINISHED IRRIGATION CAPACITY WITH PRESEASON IRRIGATION AND PLANT DENSITY FOR CORN PRODUCTION
}

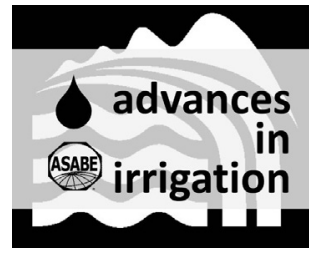

\author{
A. J. Schlegel, L. R. Stone, T. J. Dumler, F. R. Lamm
}

\begin{abstract}
Many of the irrigation systems today in the U.S. Central Great Plains no longer have the capacity to match peak irrigation needs during the summer and must rely on soil water reserves to buffer the crop from water stress. Considerable research was conducted on preseason irrigation in the U.S. Great Plains region during the 1980s and 1990s. In general, the conclusions were that in-season irrigation was more beneficial than preseason irrigation and that preseason irrigation was often not warranted. The objective of this study was to determine whether preseason irrigation would be profitable with today's lower-capacity groundwater wells at different levels of corn plant density. A field study was conducted at the Kansas State University Southwest Research-Extension Center near Tribune, Kansas, from 2006 to 2009. The study was a factorial design of preseason irrigation $(0$ and $75 \mathrm{~mm})$, irrigation capacities $\left(2.5,3.8\right.$, and $\left.5.0 \mathrm{~mm} \mathrm{~d}^{-1}\right)$, and plant density $\left(56,000,68,000\right.$, and 80,000 plants $\left.\mathrm{ha}^{-1}\right)$. Preseason irrigation increased grain yields an average of 1.0

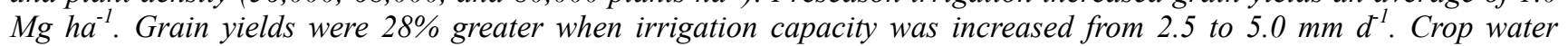
productivity was not significantly affected by irrigation capacity or preseason irrigation. Preseason irrigation was profitable at all irrigation capacities, although only slightly profitable at the highest irrigation capacity. Therefore, it may not be prudent to preseason irrigate with irrigation capacities of $5.0 \mathrm{~mm} \mathrm{~d}^{-1}$ or greater so that the water can be conserved for later use. At irrigation capacities of 2.5 and $3.8 \mathrm{~mm} \mathrm{~d}^{-1}$, a seeding rate of 68,000 seeds hal was generally more profitable than lower or higher seeding rates. A higher seeding rate $\left(80,000\right.$ seeds $\left.\mathrm{ha}^{-1}\right)$ increased profitability when irrigation capacity was increased to $5.0 \mathrm{~mm} \mathrm{~d}^{-1}$.
\end{abstract}

Keywords. Corn, Irrigation capacity, Irrigation management, Preseason irrigation.

I rrigated crop production is a mainstay of agriculture in western Kansas. However, with declining water levels in the Ogallala aquifer and increasing energy costs, optimal utilization of limited irrigation water is required. The most common crop grown under irrigation in western Kansas is corn (about $50 \%$ of the irrigated acres). Almost all of the groundwater pumped from the High Plains (Ogallala) aquifer is used for irrigation (97\% of the groundwater pumped in western Kansas in 1995; KSDA, 1997). In 1995, 3 billion $\mathrm{m}^{3}$ of water were pumped for irrigation in western Kansas, and 1.71 billion $\mathrm{m}^{3}(57 \%)$ were applied to corn (KWO, 1997). This amount of water with-

Submitted for review in August 2011 as manuscript number SW 9347; approved for publication by the Soil \& Water Division of ASABE in January 2012. Presented at the 5th National Decennial Irrigation Conference as Paper No. IRR108836.

Contribution No. 12-089-J from the Kansas Agricultural Experiment Station, Manhattan, Kansas.

The authors are Alan J. Schlegel, Professor and Soil Scientist, Kansas State University, Southwest Research-Extension Center, Tribune, Kansas; Loyd R. Stone, Professor and Soil Physicist, Department of Agronomy, Kansas State University, Manhattan, Kansas; Troy J. Dumler, Instructor and Agricultural Economist, Kansas State University, Southwest Research-Extension Center, Garden City, Kansas; and Freddie R. Lamm, ASABE Member, Professor and Irrigation Engineer, Kansas State University, Northwest Research-Extension Center, Colby, Kansas. Corresponding author: Alan J. Schlegel, Kansas State University, Southwest Research-Extension Center, 1474 State Highway 96, Tribune, KS 67879; phone: 620-376-4761; e-mail: schlegel@ksu.edu. drawal from the aquifer reduced the saturated thickness in some areas by more than $45 \mathrm{~m}$ by the year 2003 (McGuire, 2004) and has also reduced pumping flow rates. Similar problems exist in many parts of the High Plains aquifer, particularly in the Southern High Plains.

Considerable research was conducted on preseason irrigation (also referred to as preplant, off-season, or dormant season) in the U.S. Great Plains region during the 1980s and 1990s (Stone et al., 1983, 1987, 1994; Lamm and Rogers, 1985; Musick and Lamm, 1990; Rogers and Lamm, 1994). In general, the conclusions were that in-season irrigation was more beneficial than preseason irrigation and that preseason irrigation was often not warranted because overwinter precipitation could replenish a significant portion of the soil water profile. In a survey from the late 1980s that assessed water management practices of irrigators, $65 \%$ of the 455 respondents from western Kansas, western Texas, and the Oklahoma Panhandle reported that they used off-season irrigation (Kromm and White, 1990). Preseason irrigation is an irrigation management technique that is relatively unique to the semi-arid Great Plains region; it is not usually needed in the humid and semi-humid regions and is not utilized in the arid region because irrigation systems are typically designed to apply peak irrigation requirements. The Great Plains also has nearly vertical precipitation isobars (i.e., lines of nearly equal annual precipitation amounts coinciding with longitudinal lines), thus 
Table 1. Irrigation and precipitation amounts in a sprinkler-irrigated corn study, KSU Southwest Research-Extension Center, Tribune, Kansas, 2006-2009.

\begin{tabular}{|c|c|c|c|c|c|}
\hline & & 2006 & 2007 & 2008 & 2009 \\
\hline Preseason irrigation & Application date & April 4 & April 24 & April 12 & April 17 \\
\hline \multirow[t]{6}{*}{ In-season irrigation } & Initial application date & May 27 & June 22 & June 13 & June 19 \\
\hline & Final application date & Aug. 28 & Aug. 31 & Sept. 5 & Sept. 2 \\
\hline & Total amount applied (mm) & & & & \\
\hline & $2.5 \mathrm{~mm} \mathrm{~d}^{-1}$ treatment & 243 & 183 & 209 & 225 \\
\hline & $3.8 \mathrm{~mm} \mathrm{~d}^{-1}$ treatment & 320 & 257 & 278 & 299 \\
\hline & $5.0 \mathrm{~mm} \mathrm{~d}^{-1}$ treatment & 483 & 397 & 375 & 453 \\
\hline Growing season precipitation & Amount (mm) & 176 & 205 & 238 & 364 \\
\hline Non-growing season precipitation & Amount (mm) & $-{ }^{[\mathrm{a}]}$ & 381 & 107 & 217 \\
\hline
\end{tabular}

[a] Non-growing season precipitation was not measured prior to the 2006 crop.

making preseason irrigation research results more useful over the broad north-to-south expanse of the region.

Much of the previous research was conducted during a generally wetter climatic period in the Great Plains and under circumstances of ample in-season irrigation capacity. The Great Plains drought that occurred during the early part of the last decade (2000-2009) renewed producer interest and has brought new questions about preseason irrigation. In a more recent study, Stone et al. (2008) used simulation modeling to examine the effectiveness of preseason irrigation. They found that the differences in storage efficiency between spring and fall irrigation peaked at approximately 37 percentage points (storage efficiency of approximately $70 \%$ for spring and $33 \%$ for fall irrigation) when the maximum soil water during the preseason period was at approximately $77 \%$ of available soil water (ASW).

Corn yield is greatly impacted by irrigation capacity when in-season precipitation is limited. In northwest Kansas, corn yields were increased by approximately $10 \%$ when the irrigation capacity was increased from $25 \mathrm{~mm}$ every eight days to $25 \mathrm{~mm}$ every four days (Lamm et al., 2009). In the same study, increasing plant density from 66,300 to 82,300 plants $^{-1}{ }^{-1}$ increased grain yield (and water productivity) by approximately $6 \%$. In a study with subsurface drip irrigation at the same site, an irrigation capacity of $2.5 \mathrm{~mm} \mathrm{~d}^{-1}$ produced approximately $80 \%$ of maximum yield even in an extremely dry year, and an irrigation capacity of $4.3 \mathrm{~mm} \mathrm{~d}^{-1}$ produced near-maximum yields in most years (Lamm and Trooien, 2001). It was also found that increasing plant density from 55,600 to 85,200 plants $\mathrm{ha}^{-1}$ generally increased corn yields, particularly in good corn production years, without a yield penalty when irrigation was severely limited or eliminated.

Many of the irrigation systems today in the Central Great Plains are limited by available water resources. They can no longer apply peak irrigation needs during the summer and must rely on soil water reserves to buffer the crop from water stress. Therefore, this study was conducted to evaluate whether preseason irrigation would be profitable when irrigation capacity is limited and insufficient to fully meet crop requirements.

\section{MATERIALS AND MethodS}

A field study was conducted at the Kansas State University Southwest Research-Extension Center near Tribune, Kansas, from 2006 to 2009 on a deep silt loam soil (Ulys- ses silt loam; fine-silty, mixed, superactive, mesic Aridic Haplustolls). The region is semi-arid with a summer precipitation pattern and an average annual precipitation of $440 \mathrm{~mm}$. The study was a factorial design of preseason irrigation $(0$ and $75 \mathrm{~mm})$, irrigation capacity $(2.5,3.8$, and $\left.5.0 \mathrm{~mm} \mathrm{~d}^{-1}\right)$, and plant density $(56,000,68,000$, and 80,000 plants $\left.\mathrm{ha}^{-1}\right)$. The irrigation treatments were whole plots, and the plant densities were subplots. Each treatment combination was replicated four times and applied to the same plot each year. The whole plots (irrigation treatments) were approximately $36 \mathrm{~m}$ long and $18 \mathrm{~m}$ wide, and the plant population subplots were approximately $36 \mathrm{~m}$ long and $3 \mathrm{~m}$ wide (four $76 \mathrm{~cm}$ rows).

Corn was planted in late April or early May each year. The hybrids (Pioneer 33B53 in 2006, Pioneer 33B54 in 2007, Pioneer 34B99 in 2008, and Pioneer 34B94 in 2009) were all resistant to glufosinate and/or glyphosate herbicides. The study area was disked several times in the spring prior to planting to incorporate residue and form a seedbed. Pre-emergence herbicides were used for weed control along with post-emergence applications of glyphosate (2007 and 2009) or glufosinate (2006 and 2008). Nitrogen fertilizer $\left(269 \mathrm{~kg} \mathrm{~N} \mathrm{ha}^{-1}\right)$ as urea-ammonium nitrate was surface applied prior to planting, and $\mathrm{P}$ fertilizer $\left(40 \mathrm{~kg} \mathrm{P}_{2} \mathrm{O}_{5} \mathrm{ha}^{-1}\right)$ was applied with the planter. A measured length (approx. $18 \mathrm{~m}$ ) of the center two rows of all plots was machine harvested with grain yields adjusted to $0.155 \mathrm{~g} \mathrm{~g}^{-1}$ moisture (wet basis). Plant densities were determined along with the other yield components (kernels per ear and kernel mass).

The plots were irrigated with a linear-move sprinkler irrigation system that had been modified to allow water application from different span sections as needed to accomplish the randomization of plots. The preseason irrigation was applied in approximately $38 \mathrm{~mm}$ amounts in two passes several days apart to minimize runoff in April (table 1). The in-season irrigations were initiated in late May to mid-late June (table 1). All plots were irrigated in May after planting each year to aid emergence and incorporate herbicides. After in-season irrigations were initiated, the $5.0 \mathrm{~mm} \mathrm{~d}^{-1}$ treatment was applied as a weekly irrigation of about $35 \mathrm{~mm}$, the $3.8 \mathrm{~mm} \mathrm{~d}^{-1}$ treatment was applied as a weekly irrigation of about $25 \mathrm{~mm}$, and the $2.5 \mathrm{~mm} \mathrm{~d}^{-1}$ treatment was applied every two weeks as $35 \mathrm{~mm}$ (in conjunction with the $5.0 \mathrm{~mm} \mathrm{~d}^{-1}$ treatment). When abundant precipitation occurred near the time of planned irrigation events, the scheduled irrigations were not performed. This occurred once during the summers of 2006, 2007, and 2008. The final irrigation events 
were in late August to early September (table 1).

Corn in this region can extract water from a depth of approximately $2.4 \mathrm{~m}$ and will easily utilize water on these deep silt loam soils to a depth of $2 \mathrm{~m}$ (Lamm et al., 1994). Soil water within the profile was measured throughout the growing season using neutron attenuation (calibrated for this field), with probe activity centered at $0.3 \mathrm{~m}$ depth increments from 0.15 through $2.25 \mathrm{~m}$ soil depths. Care was taken to ensure that access tubes were installed with the appropriate height above ground so that all measurements were taken at consistent depths. Available soil water was calculated by subtracting unavailable water (measured previously to be $357 \mathrm{~mm}$ in the $240 \mathrm{~cm}$ profile) from measured soil water. All precipitation and irrigation inputs were measured (table 1). Seasonal crop water use was calculated by summing the soil water depletion (soil water near emergence less soil water at harvest) plus the in-season irrigation and precipitation. Non-growing season soil water accumulation was the increase in soil water from harvest to the amount at emergence the following year. Precipitation storage efficiency (without preseason irrigation) was calculated as non-growing season soil water accumulation divided by non-growing season precipitation. Storage efficiency from preseason irrigation was calculated as the difference between non-growing season accumulation with preseason irrigation compared with no preseason irrigation (averaged across plant densities) divided by the amount of preseason irrigation. Crop water productivity (WP) was calculated as the grain yield $\left(\mathrm{kg} \mathrm{ha}^{-1}\right)$ divided by seasonal crop water use $(\mathrm{mm})$. Statistical analyses were performed using the GLM procedure in SAS (version 9.1, SAS, 2009).

Local crop prices and input costs were used to perform an economic analysis to determine net return to land, management, and irrigation equipment for each treatment. Custom rates were used for all machine operations. Input costs, including the cost of seed ( $\$ 2.49$ per 1000 seeds), were kept uniform for all years. Although irrigation pumping depths (30 to $75 \mathrm{~m}$ ) and energy sources (e.g., natural gas, electric, and diesel) vary greatly within the region, a representative irrigation cost of $\$ 0.157 \mathrm{~mm}^{-1}$ was used in all calculations. Harvest prices of corn were $\$ 0.133, \$ 0.189, \$ 0.156$, and $\$ 0.136 \mathrm{~kg}^{-1}$ in $2006,2007,2008$, and 2009 , respectively.

\section{RESULTS AND DISCUSSION}

WEATHER CONDITIONS AND IRRIGATION REQUIREMENTS

Growing-season precipitation ranged from $176 \mathrm{~mm}$ in 2006 to $364 \mathrm{~mm}$ in 2009 (table 1). Normal growing season precipitation is $245 \mathrm{~mm}$; therefore, 2006 and 2007 were drier than normal years, 2009 was a wet year, and 2008 was about average. Temperatures were below normal in 2006, near normal in 2007, near normal in 2008 except for a cool August, and slightly above normal in 2009. In-season irrigations ranged from 183 to $483 \mathrm{~mm}$ depending on irrigation capacity and year (table 1). Non-growing season precipitation ranged from $107 \mathrm{~mm}$ (2008) to $381 \mathrm{~mm}$ (2007), with an average of $235 \mathrm{~mm}$.

\section{CORN GRAIN YIELD RESPONSE}

Preseason irrigation significantly increased grain yields by an average of $1.0 \mathrm{Mg} \mathrm{ha}^{-1}$ (table 2 and fig. 1). Although the interaction with irrigation capacity was not significant, the effect tended to be greater at lower irrigation capacities. For example, with 68,000 plants $\mathrm{ha}^{-1}$, preseason irrigation $(75 \mathrm{~mm})$ increased grain yield by $1.3 \mathrm{Mg} \mathrm{ha}^{-1}$ with an irrigation capacity of $2.5 \mathrm{~mm} \mathrm{~d}^{-1}$ but only by $0.4 \mathrm{Mg} \mathrm{ha}^{-1}$ with an irrigation capacity of $5.0 \mathrm{~mm} \mathrm{~d}^{-1}$. As might be expected, grain yields increased significantly with increased irrigation capacity. Grain yields (averaged across preseason irrigation and plant density) were $28 \%$ greater when the irrigation capacity increased from 2.5 to $5.0 \mathrm{~mm} \mathrm{~d}^{-1}$. This increase was greater than the $10 \%$ yield increase in northwest Kansas for a similar increase in irrigation capacity (Lamm et al., 2009). Preseason irrigation and increased irrigation capacity increased the number of kernels per ear but had little impact on kernel mass.

The optimum plant density varied with irrigation level (table 2 and fig. 1). With the two lowest irrigation capacities and without preseason irrigation, a plant density of 56,000 plants ha ${ }^{-1}$ was generally adequate. However, if preseason irrigation was applied, then a higher plant density $\left(68,000\right.$ plants $h^{-1}$ or greater) increased yields. With an irrigation capacity of $5.0 \mathrm{~mm} \mathrm{~d}^{-1}$, a plant density of 80,000 plants $\mathrm{ha}^{-1}$ provided greater yields with or without preseason irrigation.
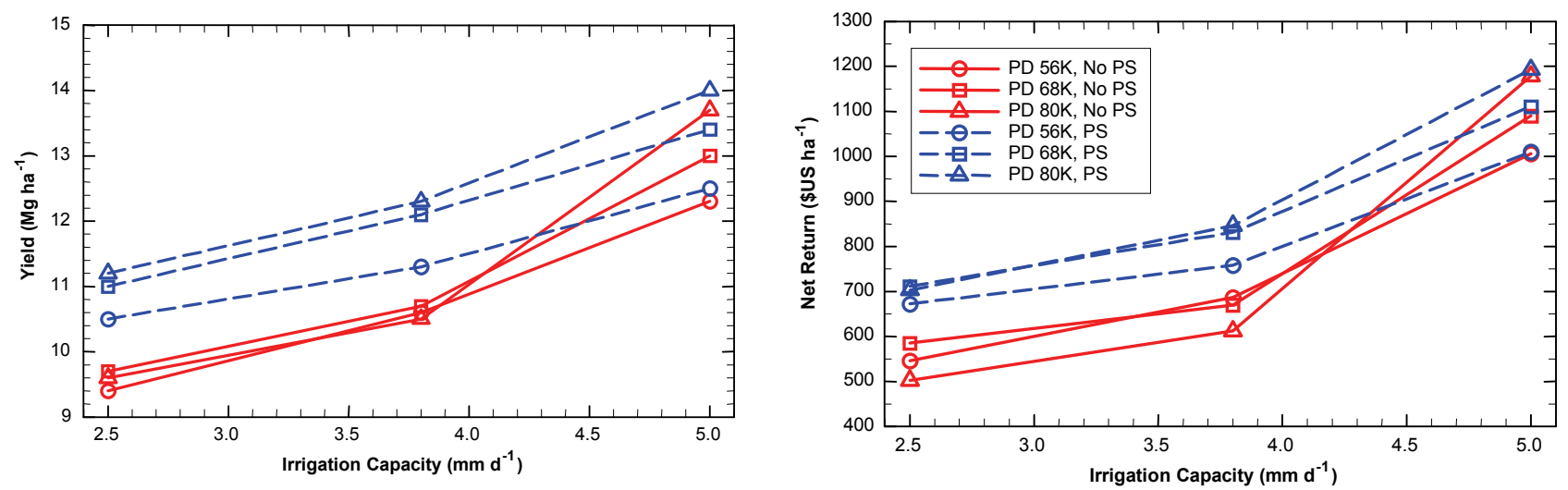

Figure 1. Average corn grain yields and net returns to land, irrigation equipment, and management as affected by irrigation capacity, plant density (PD; 56K, 68K, or $80 \mathrm{~K}_{\text {plants }} \mathrm{ha}^{-1}$ ) and preseason irrigation (PS; 0 or $75 \mathrm{~mm}$ ) in a sprinkler-irrigated corn study, KSU Southwest Research-Extension Center, Tribune, Kansas, 2006-2009. 
Table 2. Crop parameters as affected by irrigation capacity, preseason irrigation ( 0 or 75 mm), and seeding rate in a sprinkler-irrigated corn study, KSU Southwest Research-Extension Center, Tribune, Kansas, 2006-2009.

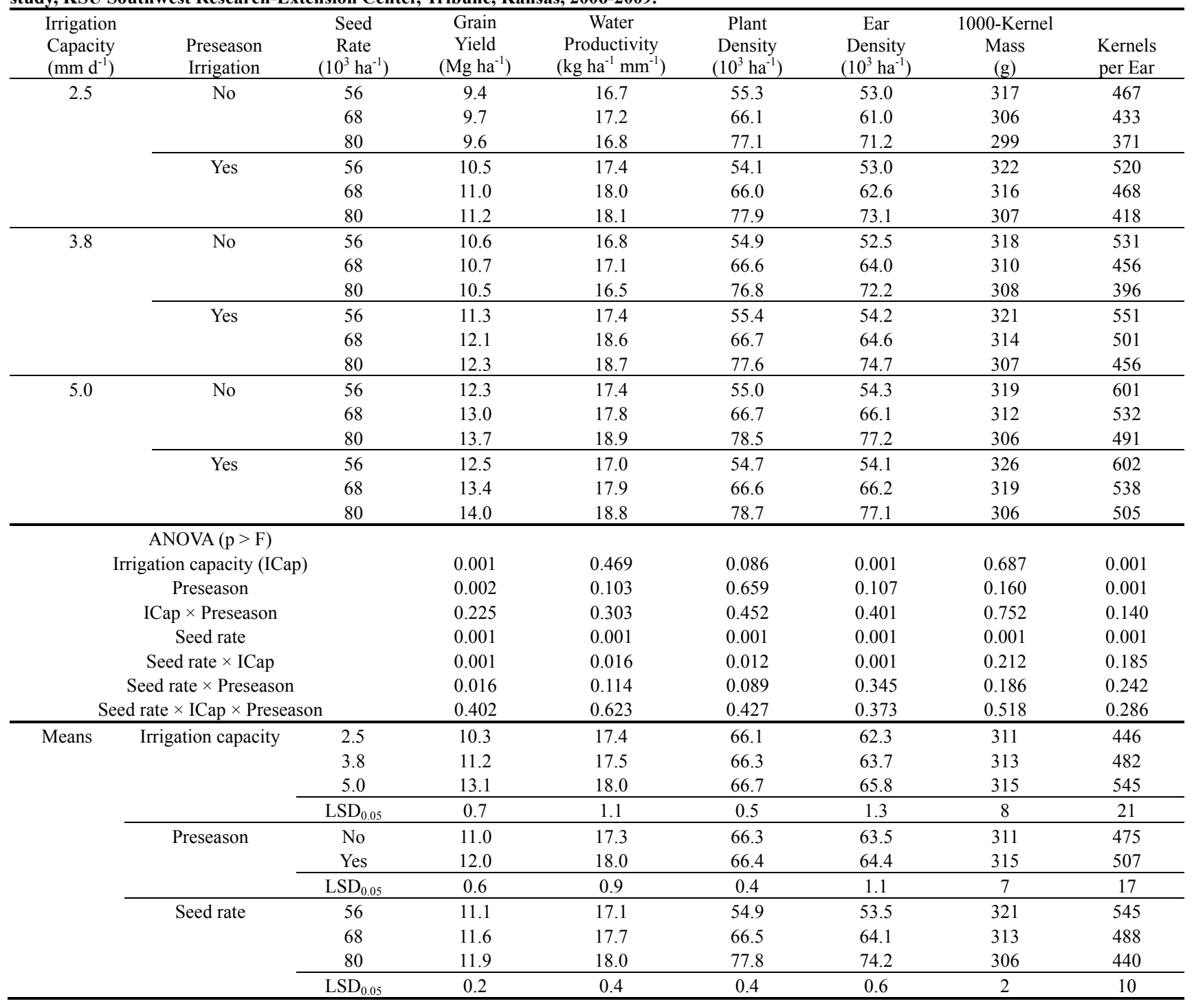

\section{Water Use Parameters}

Water productivity (WP) was not significantly affected by irrigation capacity or preseason irrigation (table 2), although the trend was for greater WP with increased water supply. This contrasts with previous research (Stone et al., 1987; Musick and Lamm, 1990), in which WP was less with preseason irrigation. Similar to grain yields, the effect of plant density varied with irrigation level. With lower irrigation levels, a plant density of 68,000 plants ha ${ }^{-1}$ tended to optimize crop water productivity. It was only at the highest irrigation capacity that higher plant densities improved WP.

Crop water use increased with irrigation capacity and preseason irrigation (table 3). Soil water at harvest increased with increased irrigation capacity, but this resulted in less soil water accumulation during the winter. Nongrowing season soil water accumulation averaged $69 \mathrm{~mm}$ (without preseason irrigation), storing approximately 29\% of the average non-growing season precipitation $(235 \mathrm{~mm})$. When preseason irrigation (about $75 \mathrm{~mm}$ ) was applied, the increase in accumulation of non-growing season water was
62,47 , and $20 \mathrm{~mm}$ for the $2.5,3.8$, and $5.0 \mathrm{~mm} \mathrm{~d}^{-1}$ irrigation capacities, respectively. Those values translate into storage efficiencies from preseason irrigation (net gain from gross irrigation amount) of $82 \%, 62 \%$, and $27 \%$ for the $2.5,3.8$, and $5.0 \mathrm{~mm} \mathrm{~d}^{-1}$ irrigation capacities, respectively. The increasing irrigation capacities having increased amounts of available soil water (ASW) at harvest (table 3) are less efficient at storing the preseason irrigation. Similarly, on this Ulysses soil, Stone et al. (2008) found storage efficiency from fall preseason irrigation amounts decreased from $80 \%$ to $30 \%$ as ASW increased from $60 \%$ to $80 \%$ of the available water capacity. Available soil water at emergence was $58 \mathrm{~mm}$ greater with preseason irrigation from a combination of the storage from preseason irrigation and greater ASW at harvest. By mid-July (near time of silking), the effect of preseason irrigation on ASW had diminished, and although numerically greater (by $33 \mathrm{~mm}$ ), was not significantly greater than without preseason irrigation. The effect of preseason irrigation was even further reduced at corn harvest, with only $20 \mathrm{~mm}$ greater ASW. Increasing irrigation capacity significantly increased ASW throughout 
Table 3. Available soil water in a $2.4 \mathrm{~m}$ profile, crop water use, and non-growing season water accumulation for corn as affected by irrigation capacity, preseason irrigation, and seeding rate in a sprinkler-irrigated corn study, KSU Southwest Research-Extension Center, Tribune, Kansas, 2006-2009.

\begin{tabular}{|c|c|c|c|c|c|c|c|}
\hline \multirow{2}{*}{$\begin{array}{l}\text { Irrigation } \\
\text { Capacity } \\
\left(\mathrm{mm} \mathrm{d}^{-1}\right) \\
\end{array}$} & \multirow{2}{*}{$\begin{array}{l}\text { Preseason } \\
\text { Irrigation }\end{array}$} & \multirow{2}{*}{$\begin{array}{l}\text { Seed Rate } \\
\left(10^{3} \mathrm{ha}^{-1}\right)\end{array}$} & \multicolumn{3}{|c|}{$\begin{array}{l}\text { Available Soil Water } \\
(\mathrm{mm} \text { in } 2.4 \mathrm{~m} \text { profile })\end{array}$} & \multirow{2}{*}{$\begin{array}{l}\text { Water } \\
\text { Use } \\
(\mathrm{mm})\end{array}$} & \multirow{2}{*}{$\begin{array}{c}\text { Non-Growing Season } \\
\text { Accumulation }{ }^{[\mathrm{a}]} \\
(\mathrm{mm})\end{array}$} \\
\hline & & & Emergence & Mid-July & Harvest & & \\
\hline \multirow[t]{6}{*}{2.5} & No & 56 & 212 & 208 & 132 & 541 & 71 \\
\hline & & 68 & 209 & 191 & 123 & 547 & 69 \\
\hline & & 80 & 204 & 189 & 118 & 547 & 71 \\
\hline & Yes & 56 & 271 & 237 & 138 & 593 & 128 \\
\hline & & 68 & 267 & 220 & 124 & 604 & 135 \\
\hline & & 80 & 275 & 220 & 126 & 610 & 135 \\
\hline \multirow[t]{6}{*}{3.8} & No & 56 & 223 & 210 & 139 & 618 & 69 \\
\hline & & 68 & 233 & 211 & 154 & 613 & 65 \\
\hline & & 80 & 230 & 213 & 144 & 620 & 76 \\
\hline & Yes & 56 & 267 & 228 & 157 & 644 & 103 \\
\hline & & 68 & 266 & 231 & 156 & 644 & 121 \\
\hline & & 80 & 272 & 232 & 152 & 654 & 128 \\
\hline \multirow[t]{6}{*}{5.0} & No & 56 & 267 & 276 & 230 & 710 & 54 \\
\hline & & 68 & 253 & 255 & 200 & 726 & 77 \\
\hline & & 80 & 268 & 269 & 217 & 725 & 72 \\
\hline & Yes & 56 & 341 & 326 & 275 & 739 & 80 \\
\hline & & 68 & 336 & 316 & 257 & 751 & 93 \\
\hline & & 80 & 328 & 310 & 250 & 751 & 90 \\
\hline \multicolumn{8}{|c|}{$\operatorname{ANOVA}(\mathrm{p}>\mathrm{F})$} \\
\hline \multicolumn{3}{|c|}{ Irrigation capacity (ICap) } & 0.010 & 0.002 & 0.001 & 0.001 & 0.001 \\
\hline \multicolumn{3}{|c|}{ Preseason irrigation } & 0.001 & 0.062 & 0.266 & 0.001 & 0.001 \\
\hline \multicolumn{3}{|c|}{ ICap $\times$ Preseason irrigation } & 0.647 & 0.726 & 0.587 & 0.010 & 0.001 \\
\hline \multicolumn{3}{|c|}{ Seed rate } & 0.779 & 0.087 & 0.076 & 0.001 & 0.002 \\
\hline \multicolumn{3}{|c|}{ Seed rate $\times$ ICap } & 0.692 & 0.368 & 0.173 & 0.059 & 0.156 \\
\hline \multicolumn{3}{|c|}{ Seed rate $\times$ Preseason irrigation } & 0.985 & 0.818 & 0.820 & 0.546 & 0.424 \\
\hline \multicolumn{3}{|c|}{ Seed rate $\times$ ICap $\times$ Preseason irrigation } & 0.389 & 0.908 & 0.625 & 0.749 & 0.303 \\
\hline \multirow[t]{11}{*}{ Means } & Irrigation capacity & 2.5 & 240 & 211 & 127 & 574 & 101 \\
\hline & & 3.8 & 248 & 221 & 150 & 632 & 94 \\
\hline & & 5.0 & 299 & 292 & 238 & 734 & 78 \\
\hline & & $\mathrm{LSD}_{0.05}$ & 38 & 43 & 45 & 10 & 10 \\
\hline & Preseason irrigation & No & 233 & 225 & 162 & 627 & 69 \\
\hline & & Yes & 291 & 258 & 182 & 666 & 113 \\
\hline & & $\mathrm{LSD}_{0.05}$ & 31 & 35 & 37 & 8 & 8 \\
\hline & Seed rate & 56 & 264 & 247 & 179 & 641 & 84 \\
\hline & & 68 & 261 & 237 & 169 & 648 & 93 \\
\hline & & 80 & 263 & 239 & 168 & 651 & 95 \\
\hline & & $\mathrm{LSD}_{0.05}$ & 9 & 10 & 10 & 5 & 6 \\
\hline
\end{tabular}

[a] Fallow accumulation includes only 2007, 2008, and 2009 data.

the growing season. Seeding rate had minimal effect on ASW at emergence, but increased seeding rate tended to increase crop water use, decrease soil water at harvest, and increase over-winter soil water accumulation.An increase in ASW in the soil profile at emergence from preseason irrigation occurred below $30 \mathrm{~cm}$ to a depth of at least $240 \mathrm{~cm}$ (extent of measurements) but not in the surface 30 $\mathrm{cm}$ (table 4). Lamm et al. (2009) reported no difference in ASW in a $2.4 \mathrm{~m}$ soil profile at emergence due to irrigation capacity. However, in the current study, an increase in irrigation capacity resulted in increased ASW at planting from 60 through $180 \mathrm{~cm}$. This suggests that drainage losses will be increased when the amount of irrigation is increased either through preseason irrigation or higher irrigation capacity. The drainage rate for this Ulysses soil was shown to be 5,1 , and $0.1 \mathrm{~mm} \mathrm{~d}^{-1}$ at profile available water amounts of $100 \%, 85 \%$, and $65 \%$ of maximum, respectively (Stone et al., 2008). Seeding rate had no effect on ASW at emergence at any depth in the profile, which agreed with earlier reports (Lamm et al., 2009).

\section{Net Returns}

Preseason irrigation was found to be profitable at all irrigation capacities (table 5 and fig. 1), although the difference was minimal at the $5.0 \mathrm{~mm} \mathrm{~d}^{-1}$ irrigation capacity. At the two lower irrigation capacities, a seeding rate of 68,000 seeds $\mathrm{ha}^{-1}$ was generally the most profitable. However, the highest irrigation capacity benefited from a seeding rate of 80,000 seeds ha ${ }^{-1}$. 
Table 4. Available soil water $(\mathrm{mm})$ at emergence in a $240 \mathrm{~cm}$ profile as affected by irrigation capacity, preseason irrigation (0 or 75 mm), and seeding rate in a sprinkler-irrigated corn study, KSU Southwest Research-Extension Center, Tribune, Kansas, $2006-2009$.

\begin{tabular}{|c|c|c|c|c|c|c|c|c|c|c|}
\hline \multirow{2}{*}{$\begin{array}{l}\text { Irrigation Capacity } \\
\left(\mathrm{mm} \mathrm{d}^{-1}\right)\end{array}$} & \multirow{2}{*}{$\begin{array}{l}\text { Preseason } \\
\text { Irrigation }\end{array}$} & \multirow{2}{*}{$\begin{array}{c}\text { Seed Rate } \\
\left(10^{3} \mathrm{ha}^{-1}\right)\end{array}$} & \multicolumn{8}{|c|}{ Soil Depth (cm) } \\
\hline & & & $0-30$ & $30-60$ & $60-90$ & $90-120$ & $120-150$ & $150-180$ & $180-210$ & $210-240$ \\
\hline \multirow[t]{6}{*}{2.5} & No & 56 & 47 & 29 & 25 & 23 & 23 & 23 & 22 & 21 \\
\hline & & 68 & 45 & 29 & 26 & 24 & 22 & 21 & 21 & 23 \\
\hline & & 80 & 46 & 26 & 24 & 22 & 21 & 20 & 21 & 24 \\
\hline & Yes & 56 & 49 & 37 & 35 & 32 & 31 & 29 & 29 & 29 \\
\hline & & 68 & 48 & 38 & 36 & 32 & 29 & 28 & 28 & 28 \\
\hline & & 80 & 49 & 36 & 35 & 33 & 32 & 29 & 30 & 31 \\
\hline \multirow[t]{6}{*}{3.8} & No & 56 & 47 & 30 & 24 & 25 & 24 & 24 & 25 & 24 \\
\hline & & 68 & 48 & 30 & 27 & 26 & 25 & 26 & 26 & 25 \\
\hline & & 80 & 47 & 30 & 26 & 25 & 25 & 26 & 26 & 25 \\
\hline & Yes & 56 & 49 & 38 & 34 & 33 & 31 & 29 & 27 & 26 \\
\hline & & 68 & 50 & 36 & 34 & 33 & 29 & 27 & 30 & 26 \\
\hline & & 80 & 50 & 39 & 34 & 33 & 31 & 28 & 28 & 29 \\
\hline \multirow[t]{6}{*}{5.0} & No & 56 & 50 & 36 & 33 & 32 & 30 & 29 & 29 & 29 \\
\hline & & 68 & 47 & 35 & 32 & 30 & 30 & 29 & 25 & 25 \\
\hline & & 80 & 49 & 36 & 34 & 32 & 30 & 31 & 29 & 28 \\
\hline & Yes & 56 & 53 & 42 & 45 & 44 & 42 & 41 & 38 & 37 \\
\hline & & 68 & 52 & 42 & 46 & 43 & 41 & 39 & 38 & 36 \\
\hline & & 80 & 51 & 43 & 44 & 42 & 40 & 37 & 36 & 34 \\
\hline \multicolumn{11}{|c|}{$\operatorname{ANOVA}(\mathrm{p}>\mathrm{F})$} \\
\hline \multicolumn{3}{|c|}{ Irrigation capacity (ICap) } & 0.270 & 0.088 & 0.001 & $<0.001$ & 0.002 & 0.009 & 0.052 & 0.138 \\
\hline \multicolumn{3}{|c|}{ Preseason } & 0.116 & 0.003 & $<0.001$ & $<0.001$ & $<0.001$ & 0.012 & 0.008 & 0.027 \\
\hline \multicolumn{3}{|c|}{ ICap $\times$ Preseason } & 0.934 & 0.919 & 0.675 & 0.685 & 0.526 & 0.525 & 0.476 & 0.595 \\
\hline \multicolumn{3}{|c|}{ Seed rate } & 0.519 & 0.687 & 0.778 & 0.765 & 0.535 & 0.659 & 0.991 & 0.346 \\
\hline \multicolumn{3}{|c|}{ Seed rate $\times$ ICap } & 0.042 & 0.072 & 0.837 & 0.836 & 0.836 & 0.945 & 0.565 & 0.297 \\
\hline \multicolumn{3}{|c|}{ Seed rate $\times$ Preseason } & 0.387 & 0.244 & 0.767 & 0.932 & 0.547 & 0.670 & 0.664 & 0.994 \\
\hline \multicolumn{3}{|c|}{ Seed rate $\times$ ICap $\times$ Preseason } & 0.223 & 0.818 & 0.451 & 0.513 & 0.670 & 0.535 & 0.569 & 0.451 \\
\hline \multirow[t]{11}{*}{ Means } & Capacity & 2.5 & 47 & 33 & 30 & 28 & 26 & 25 & 25 & 26 \\
\hline & & 3.8 & 48 & 34 & 30 & 29 & 27 & 27 & 27 & 26 \\
\hline & & 5.0 & 50 & 39 & 39 & 37 & 35 & 34 & 32 & 31 \\
\hline & & $\mathrm{LSD}_{0.05}$ & 4 & 6 & 5 & 4 & 5 & 6 & 6 & 6 \\
\hline & eason & No & 47 & 31 & 28 & 27 & 25 & 25 & 25 & 25 \\
\hline & & Yes & 50 & 39 & 38 & 36 & 34 & 32 & 32 & 31 \\
\hline & & $\mathrm{LSD}_{0.05}$ & 3 & 5 & 4 & 4 & 4 & 5 & 5 & 5 \\
\hline & rate & 56 & 49 & 35 & 33 & 32 & 30 & 29 & 28 & 28 \\
\hline & & 68 & 48 & 35 & 33 & 31 & 29 & 28 & 28 & 27 \\
\hline & & 80 & 49 & 35 & 33 & 31 & 30 & 29 & 28 & 28 \\
\hline & & $\mathrm{LSD}_{0.05}$ & 1 & 1 & 1 & 1 & 2 & 2 & 2 & 2 \\
\hline
\end{tabular}

Table 5. Net return to land, irrigation equipment, and management $\left(\$ \mathrm{ha}^{-1}\right)$ from preseason irrigation $(0$ or $75 \mathrm{~mm})$ at three irrigation capacities and three seeding rates in a sprinkler-irrigated corn study, KSU Southwest Research-Extension Center, Tribune, Kansas, 20062009.

\begin{tabular}{ccccc}
\hline \multirow{2}{*}{$\begin{array}{c}\text { Irrigation } \\
\text { Capacity } \\
\left(\mathrm{mm} \mathrm{d}^{-1}\right)\end{array}$} & $\begin{array}{c}\text { Preseason } \\
\text { Irrigation }\end{array}$ & \multicolumn{3}{c}{$\begin{array}{c}\text { Seeding Rate } \\
\left(10^{3} \mathrm{ha}^{-1}\right)\end{array}$} \\
\hline 2.5 & No & 546 & 68 & 80 \\
\hline & Yes & 672 & 561 & 502 \\
& No & 686 & 670 & 703 \\
\hline 3.8 & Yes & 758 & 831 & 846 \\
& No & 1006 & 1090 & 1178 \\
& Yes & 1010 & 1111 & 1193 \\
\hline 5.0 & & & &
\end{tabular}

\section{CONCLUSiOnS}

Corn grain yields responded positively to preseason irrigation and increases in irrigation capacity. This yield increase generally resulted from increases in kernels per ear, suggesting that the grain filling stage was less affected by these two factors. Grain yield increased $28 \%$ by increasing the irrigation capacity from 2.5 to $5.0 \mathrm{~mm} \mathrm{~d}^{-1}$, which is considerably greater than reported in earlier work (Lamm et al., 2009), which showed an increase of $10 \%$ with a similar increase in irrigation capacity. Preseason irrigation increased grain yields by approximately $9 \%$ and was profitable at all irrigation capacities, although the differences were small at $5.0 \mathrm{~mm} \mathrm{~d}^{-1}$ irrigation capacity. Therefore, it may not be prudent to preseason irrigate with irrigation capacities of $5.0 \mathrm{~mm} \mathrm{~d}^{-1}$ or greater so that the water can be conserved for later use. Seeding rate should be adjusted for the amount of irrigation water available from both irrigation capacity and preseason irrigation. At irrigation capacities of 2.5 and $3.8 \mathrm{~mm} \mathrm{~d}^{-1}$, a seeding rate of 68,000 seeds ha ${ }^{-1}$ was generally more profitable than lower or higher seeding rates. However, a higher seeding rate $\left(80,000\right.$ seeds $\left.\mathrm{ha}^{-1}\right)$ increased profitability when the irrigation capacity was increased to $5.0 \mathrm{~mm} \mathrm{~d}^{-1}$. With the anticipated continuing decrease of irrigation capacities above the Ogallala Aquifer, producers will need to consider the benefits from adjustment of plant population and limited use of preseason irrigation for profitable corn production.

\section{ACKNOWLEDGEMENTS}

This research was supported in part by the Ogallala Aq- 
uifer Program, a consortium between the USDA Agricultural Research Service, Kansas State University, Texas AgriLife Research, Texas AgriLife Extension Service, Texas Tech University, and West Texas A\&M University.

\section{REFERENCES}

Kromm, D. E., and S. E. White. 1990. Conserving water in the High Plains. Manhattan, Kans.: Kansas State University, Department of Geography.

KSDA. 1997. Kansas reported water use summary, calendar year 1995. Topeka, Kans.: Kansas Department of Agriculture.

KWO. 1997. 1995 Kansas irrigation water use. Topeka, Kans.: Kansas Water Office.

Lamm, F. R., and D. H. Rogers. 1985. Soil water recharge function as a decision tool for preseason irrigation. Trans. ASAE 28(5): 1521-1525.

Lamm, F. R., and T. P. Trooien. 2001. Irrigation capacity and plant population effects on corn production using SDI. In Proc. Irrigation Assn. Int'l. Irrigation Technical Conf., 73-80. Falls Church, Va.: Irrigation Association.

Lamm, F. R., D. H. Rogers, and H. L. Manges. 1994. Irrigation scheduling with planned soil water depletion. Trans. ASAE 37(5): 1491-1497.

Lamm, F. R., R. M. Aiken, and A. A. Abou Kheira. 2009. Corn yield and water use characteristics as affected by tillage, plant density, and irrigation. Trans. ASABE 52(1): 133-143.

McGuire, V. L. 2004. Water-level changes in the High Plains Aquifer, predevelopment to 2003 and 2002 to 2003. Fact Sheet FS-2004-3097. Lincoln, Neb.: U.S. Geological Survey.

Musick, J. T., and F. R. Lamm. 1990. Preplant irrigation in the central and southern High Plains: A review. Trans. ASAE 33(6): 1834-1842.

Rogers, D. H., and F. R. Lamm. 1994. Soil water survey after corn harvest in northwest Kansas. Applied Eng. in Agric. 10(1): 3740.

SAS. 2009. SAS OnlineDoc. 9.1.3. Cary, N.C.: SAS Institute, Inc. Available at: http://support.sas.com/onlinedoc/913/ docMainpage.jsp.

Stone, L. R., C. G. Carlson, T. L. Hanson, R. E. Gwin Jr., P. Gallagher, and M. L. Horton. 1983. Amount of profile water in early spring resulting from increased profile water in fall. SSSA J. 47(2): 305-309.

Stone, L. R., R. E. Gwin Jr., P. J. Gallagher, and M. J. Hattendorf. 1987. Dormant-season irrigation: Grain yield, water use, and water loss. Agron. J. 79(4): 632-636.

Stone, L. R., A. J. Schlegel, F. R. Lamm, and W. E. Spurgeon. 1994. Storage efficiency of preplant irrigation. J. Soil Water Cons. 49(1): 72-76.

Stone, L. R., F. R. Lamm, A. J. Schlegel, and N. L. Klocke. 2008. Storage efficiency of off-season irrigation. Agron. J. 100(4): 1185-1192. 